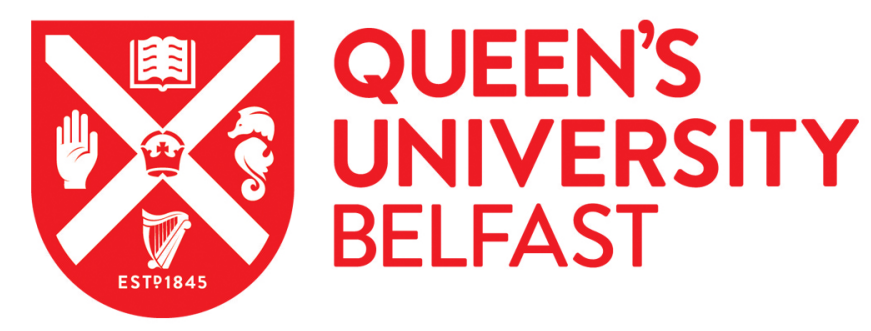

\title{
The Credible Commitment Problem and Multiple Armed Groups: FARC Perceptions of Insecurity During Disarmament in the Colombian Peace Process
}

Thomson, A. (2020). The Credible Commitment Problem and Multiple Armed Groups: FARC Perceptions of Insecurity During Disarmament in the Colombian Peace Process. Conflict, Security and Development, 20(4), 497-517. https://doi.org/10.1080/14678802.2020.1794139

Published in:

Conflict, Security and Development

Document Version:

Peer reviewed version

Queen's University Belfast - Research Portal:

Link to publication record in Queen's University Belfast Research Portal

Publisher rights

Copyright 2020 T \& F. This work is made available online in accordance with the publisher's policies. Please refer to any applicable terms of use of the publisher.

\section{General rights}

Copyright for the publications made accessible via the Queen's University Belfast Research Portal is retained by the author(s) and / or other copyright owners and it is a condition of accessing these publications that users recognise and abide by the legal requirements associated with these rights.

Take down policy

The Research Portal is Queen's institutional repository that provides access to Queen's research output. Every effort has been made to ensure that content in the Research Portal does not infringe any person's rights, or applicable UK laws. If you discover content in the Research Portal that you believe breaches copyright or violates any law, please contact openaccess@qub.ac.uk. 
The Credible Commitment Problem and Multiple Armed Groups: FARC Perceptions of Insecurity During Disarmament in the Colombian Peace Process 


\begin{abstract}
Insecurities associated with the credible commitment problem during disarmament, demobilisation, and reintegration (DDR) processes are usually examined within a dyadic relationship between the government and a rebel group, ignoring how these insecurities play themselves out in the context of multiple warring parties. In addition, most studies on these dynamics take an overview macro-perspective, leaving out micro-dynamics such as how insecurity is experienced by those undertaking the disarmament process. This paper examines FARC members' perception of insecurity and threat during the disarmament process in Colombia in the context of multiple armed groups. Drawing on semi-structured interviews with FARC combatants in three different demobilisation camps during the process of disarmament, this paper sheds light on how credible commitment problems between the FARC and the Colombian government were influenced by the presence of additional armed actors and how associated insecurities are perceived by combatants who are disarming vis-à-vis various armed actors.
\end{abstract}

Key words: FARC, multi-party conflict, disarmament, Colombia, peace process Word count: 8,214 words - excluding reference list, end notes, abstract and title. 


\section{Introduction}

Insurgent disarmament after a negotiated settlement to civil conflict can be difficult. One issue is that insurgent disarmament can be beset by credible commitment problems. Credible commitment problems are similar to a security dilemma in which both sides (but particularly those disarming) fear the other side will renege on their promises and/or violently target them when they are vulnerable, which can result in delays to disarmament or even a return to fighting. ${ }^{1}$ In this article I highlight how the presence of multiple armed groups excluded from government-insurgent negotiations and corresponding peace processes can influence the dynamics in the credible commitment problem during insurgent disarmament. Insurgent groups often trust the government based on the government's interactions with other armed groups. ${ }^{2}$ In addition, insurgents undergoing disarmament can experience security dilemmas vis-à-vis excluded armed groups, akin to spoilers. ${ }^{3}$

In this article I concentrate on Fuerzas Armadas Revolucionarias de Colombia (FARC) members' perceptions of insecurity vis-à-vis various armed actors during their disarmament process in Colombia. More specifically, I describe FARC perceptions of insecurity during their disarmament emanating from other potential rivals such as paramilitary actors, criminal bands, and the country's smaller active insurgent group, the Ejército de Liberación Nacional (ELN). In doing so, I explore how armed groups external to the government-FARC peace process influenced the government-FARC commitment problem during FARC disarmament. To do this, I adopt an exploratory approach based on interviews and surveys with FARC members during their disarmament process in three demobilisation camps.

This article is descriptive of these perceptions of threat and offers a window into the dynamics of how insecurity is experienced by disarming FARC members. This article makes a contribution to the literature on commitment problems by highlighting how FARC members' trust in the government's commitment to peace was influenced by excluded armed groups as well as how FARC perceived threats vis-à-vis these other excluded armed groups. ${ }^{4}$ It speaks to the broader literatures on inter-group interactions in multi-party conflicts and in multi-party peace processes. $^{5}$ It also makes a contribution to studies on how lived experiences and perspectives of insurgents shape the prospects for successful disarmament, demobilization and reintegration (DDR). ${ }^{6}$

This article frames these issues using the literatures on credible commitment problems, multiple armed groups, and spoilers. It then presents a background to the Colombian peace 
process. After providing a brief overview of the research design, it examines FARC perceptions of threat.

\section{Credible commitment problems and the security of disarming ex-combatants}

Negotiated settlements in civil war resolution attempts are prone to credible commitment problems and associated security dilemmas. ${ }^{7}$ Warring parties on both sides of a dispute can never be certain of the other's true intentions and often fear that the other side will renege on their promises. These insecurities associated with commitment problems are at their most intense during insurgent disarmament. ${ }^{8}$ The successful termination of civil war through a peace agreement requires that one side, usually insurgents, give up their weapons and reintegrate into society. In this situation, governments do not always trust that rebel groups will completely demilitarise and fear that they might seek further concessions through force. In turn, rebel groups are particularly apprehensive of laying down their arms in case the government make use of its advantageous position to wipe out its enemies when they are most vulnerable.

This makes insurgent disarmament a difficult process, as well as their demobilisation and reintegration. Rebel insecurity has often been proffered as reasons for insurgent groups rearming and abandoning peace processes, hiding weapons, or behind demands for enhanced security provisions for those ex-combatants undergoing disarmament. ${ }^{9}$ For example, in Northern Ireland after signing the Good Friday Agreement in 1998, the Irish Republican Army (IRA) were reluctant to disarm citing the failure of the withdrawal of British troops and watered-down security sector reform. ${ }^{10}$ The IRA did not formally relinquish weapons until late 2005, well after the May 2000 deadline outlined in the Good Friday Agreement. Even when the IRA officially disarmed, some in the organisation ostensibly kept hidden weapon caches in various rural areas across Northern Ireland in case tensions flared again. ${ }^{11}$ As a result of these insecurities and their associated potential outcomes, existing research emphasises that mitigating commitment problems are key to the durability of conflict-ending agreements, whether through power-sharing arrangements, security sector reform, or third party guarantees. ${ }^{12}$

Existing studies tend to conceive of these commitment problems as dyadic between a government and rebel group, largely leaving out how armed actors excluded from the negotiations and corresponding peace process affect these interactions. Yet research suggests that the presence of other armed actors can influence government-rebel commitment problems. ${ }^{13}$ For example, Kirschner argues that information about opponents, such as their 
behaviour during previous peace attempts with other armed actors, colours the extent to which groups trust their rivals. ${ }^{14}$ Similarly, research has shown that rebel groups compare negotiations and the terms and conditions that governments make with other armed actors. ${ }^{15} \mathrm{In}$ an alternative scenario, governments might find it convenient to turn a blind eye to inter-group fighting to attain an advantage over their primary rivals, which can influence insurgent group perceptions in the government's commitment to peace. ${ }^{16}$ Thus, in multi-party civil wars where governments conduct peace negotiations with one armed actor and exclude others, the successive iterations between groups provides scope for rebel groups to compare the deal they get to others.

In addition to this, ex-combatants undergoing DDR processes can experience security threats directly from other extra-dyadic warring factions. Armed groups left out of peace agreements or processes often perpetrate post-accord violence, and sometimes against groups or individuals who are disarming or attempting to reintegrate. ${ }^{17}$ Indeed, spoilers are major obstacles to peace, including where such groups violently target ex-combatants. ${ }^{18}$ Progovernment militias, in particular, as anti-insurgent forces, have undermined peace attempts, often targeting demobilizing or former rebels. ${ }^{19}$ Enduring rivalries between groups provide incentives to keep on fighting and provide for self-defence. ${ }^{20}$ More broadly, demobilizing or demobilised individuals are often violently targeted by former comrades in arms, victims, or even members of the public. ${ }^{21}$ Where other armed groups continue to operate during an insurgent-government peace agreement, members of the disarming and demobilizing insurgent faction can experience threats to their personal safety from a number of possible sources. Consequently, research has emphasised the need for security for those undergoing DDR. ${ }^{22}$

Finally, most research into the credible commitment problem focuses on the macrofeatures of ex-combatant (in)security during DDR processes. Little attention has been cast on how ex-combatants' perceive threats to their safety in these contexts. One notable exception is Nussio's study on the narratives of personal security of demobilizing members of a Colombian paramilitary group. ${ }^{23}$ Others have also examined how satisfied ex-combatants are with their DDR process, with a keen eye for improving DDR mechanisms. ${ }^{24}$ Research has yet to address both how this context of multiple armed groups influences perceptions of the commitment of the government and insurgent group perceptions of insecurity vis-à-vis a plethora of armed factions during disarmament. This study provides an initial bridge over these gaps by exploring how FARC members perceived threats to their personal and collective safety emanating from various armed groups during their disarmament process in 2017. 


\section{Background: FARC peace process and disarmament}

Since the 1960s, Colombia has experienced a protracted civil war involving multiple warring parties. The main cleavage has been between the government of Colombia and various revolutionary left-wing guerrilla groups, primarily the FARC and the ELN, but also has included multiple smaller rebel forces such as Movimiento 19 de Abril (M-19), Ejército Popular de Liberación (EPL), Partido Revolucionario de Trabajadores de Colombia (PRT) and others. Right-wing anti-insurgent forces such as the umbrella group Autodefensas Unidas de Colombia (AUC), referred to as 'paramilitaries' in Colombia, constituted powerful 'interfield' rivals with the FARC, ELN and other rebel groups. ${ }^{25}$ They espoused an anti-communist agenda with (clandestine) connections to state institutions and Colombia's armed forces in their counterinsurgency campaigns.

There have been a few attempts at brokering peace in Colombia. Rather than bring all warring parties to the table at once, the Colombian government has attempted to negotiate with one group at a time. These negotiations and corresponding peace processes have tended to exclude other groups and have often been beset by spoilers. ${ }^{26}$ For example, during the former president Belisario Betancur's administration (1982-1986), government-FARC negotiations led to a ceasefire and the formation of the Unión Patriótica (UP), the left-wing political party founded by the FARC and the Colombian Communist Party. However, after an estimated 3,000 UP members were murdered between 1986 and 1995, including the assassinations of two of the UP's presidential candidates (primarily by paramilitary forces and rogue government agents), conflict resumed. ${ }^{27}$ Then, in the early 1990s the government reached an agreement for the demobilisation of various smaller rebel groups such as the M-19, to which paramilitary forces also responded violently, including killing an M-19 candidate for president. ${ }^{28}$ The government of President Andrés Pastrana (1998-2002) also attempted to negotiate a settlement with the FARC. Ultimately these talks also collapsed, partially due to continued activities of external armed actors. ${ }^{29}$ For example, in October 2000, the AUC attempted to prevent the government passing a law that freed FARC prisoners by kidnapping six Colombian politicians, forcing the FARC to demand government action against paramilitary forces. ${ }^{30}$

Between 2003 and 2006 the Uribe government (in office 2002-2010) reached an agreement and hosted a demobilisation program with the paramilitary AUC. By 2006, over 30,000 paramilitary members had disarmed and demobilized. However, a small percentage of paramilitary members (officially estimated at less than 10 per cent) did not participate and formed new paramilitary groups, building their ranks with new recruits. ${ }^{31}$ Groups such as the 
Las Autodefensas Gaitanistas de Colombia (AGC), Los Paisas, Águilas Negras, or Los Rastrojos, among many other groups emerged in place of the dismantled AUC. Initially, the government of Colombia dismissed these new actors as a-political criminal gangs interested solely in narco-trafficking, known as 'BACRIM' (short for bandas criminales). Yet, many observers, researchers, and government officials now refer to such groups as 'successor paramilitary groups' or 'new paramilitary groups', noting similar leaders, objectives and tactics as their AUC predecessors. ${ }^{32}$

Under the Santos presidency (2010-2018), government-FARC negotiations to end conflict began in 2012 in Havana, Cuba and, after rejection in a national referendum, a revised landmark peace deal was signed by both parties in November 2016. The six-point governmentFARC deal was comprehensive, addressing key areas of the conflict. However, these government-FARC negotiations and the corresponding peace process excluded other armed actors such as the ELN (who had separate secretive talks with the government) and various successor paramilitary and BACRIM groups, which continued fighting. As part of the provisions for ending the conflict, the two parties agreed to a FARC DDR process (referred to in Colombia as a collective 'normalización' and 'reincorporación'). They also agreed that the FARC would join the democratic process as a political party and individuals would reintegrate into civilian life. The peace agreement also established third-party guarantees in the form of a tri-partite monitoring and verification mechanism, made up of representatives from the Colombian government, the FARC, and United Nations (UN), known as the Mecanismo de Monitoreo y Verificación (MMV) to oversee this process. For the demobilisation and disarmament of the FARC, the government helped set up 26 demobilisation camps, called zonas veredales transitorias de normalización (ZVTN), spread out across the country. These were designed, according to the Colombian High Commission for Peace, to 'guarantee the ceasefire and disarmament as well as begin preparations for the reincorporation of FARC into civil society and their transition to a legal [political party]. ${ }^{33}$ These ZVTN camps varied in size, some with over 600 individual fighters and others with little over 50 . The camps were set up in rural areas close to where FARC fronts operated. Between January and March 2017 around 6,000-7,000 FARC fighters entered these ZVTN camps.

The government-FARC agreement established a 180-day ceasefire and weapons decommissioning multi-stage timeline once the FARC entered the camps. After some delays, partially due to the setbacks from the referendum result and partially due to government capacity, this took place over a 4-month period between April and July, 2017. The FARC's 
disarmament included various procedures and stages, including identification, registration, monitoring and verification, collection, storage, disablement, removal and final disposition. The UN identified, registered and verified possession of weapons, it then collected them and eventually deposited them into UN storage containers which stayed in the ZVTN camps for a few weeks. The containers were then eventually removed from the camps and the UN disposed of them by using the weapons as material for building three monuments. ${ }^{34}$ Individuals were provided with certificates to confirm completion of the disarmament process, and which also authorised them to begin their formal reintegration into civil society. The UN declared the FARC's full disarmament and an end to the fighting on the 26 of June, 2017 with the last containers of weapons leaving FARC camps the $15^{\text {th }}$ of August, 2017..$^{35}$

As part of the terms of the government-FARC agreement, the Colombian government agreed to establish various mechanisms for the security and protection of FARC members in the process of disarmament and reintegration as well as for broader vulnerable sections of society. The text of the signed peace agreement recognised that the government of Colombia would 'guarantee the implementation of the necessary measures for integral and effective action against criminal organisations responsible for homicide and massacres and against those who target human rights defenders, social movements, and political movements as well as those that threaten or target individuals involved in the implementation of the peace agreement and the construction of peace, including against those criminal organisations that have been identified as successor paramilitary groups and their networks' ${ }^{36}$ This included, among other things, a National Commission for Security Guarantees, an organisation to protect rural communities and organisations, an elite police unit, among others. ${ }^{37}$ Some of these security measures were set in place to protect FARC members specifically from successor paramilitary actors, which the FARC had pressed for during the negotiations. In addition to this, the Colombian military and the Police provided security protection perimeter of $1 \mathrm{~km}$ around the ZVTN demobilisation camps for the transition period. Both maintained bases just outside the camps. They were not allowed to enter the camps unless authorised by the independent monitoring team (the MMV).

The Colombian government has taken some significant steps in the fight against criminal bands and successor paramilitary groups. ${ }^{38}$ However, according to United Nations figures, 173 ex-FARC members and an estimated 324 (confirmed 303) social leaders have subsequently been assassinated since signing the peace agreement in 2016 to December 2019. ${ }^{39}$ 
Armed groups outside of the government-FARC peace deal have continued to target demobilizing FARC members and those that support the peace process. ${ }^{40}$

\section{Research design}

To examine FARC perceptions of threat vis-à-vis various armed groups, I adopt an exploratory approach focusing on their personal narratives. I draw on semi-structured interviews and surveys with demobilizing FARC members during their disarmament in three ZVTN camps. I conducted the semi-structured interviews using a 50-question survey about the respondent's perception of threat emanating from various actors. Out of the 22 participants who agreed to be interviewed, 16 respondents also agreed to fill in the survey. In these cases, I conducted the interview whilst filling in respondents' answers to questions from the survey, double-checking at each question if respondents were happy with the answer. For the 6 respondents that agreed to participate in a semi-structured interview, but declined to participate in the survey, I asked similar sets of questions but only noted their responses without filling in the survey. I also spoke more informally to numerous other FARC members who provided useful contextual information.

Crucially, I completed these interviews across two different timeframes during FARC disarmament, once in April 2017, after FARC combatants had entered the ZVTN camps but just before the disarmament process had begun, and again in July 2017, during the process of disarmament while their weapons were held in UN shipping containers waiting to be withdrawn and decommissioned.

In order to get a contrasting sample of perspectives, I conducted these interviews in three different FARC ZVTN demobilisation camps across different regions of Colombia; one outside of Puerto Frasquillo, near Tierralta, Córdoba ('Gallo'), San José del Guaviare (Este y Oeste) and in Buenos Aires, Cauca ('La Elvira'). This ensured a geographical spread of respondents and helped to capture the perspectives of various fronts and individuals in contrasting contexts. Rival actors such as the Colombian armed forces, paramilitary actors, and the ELN had varying levels of presence and different interactions with the FARC in each of these areas. For example, Tierralta in Córdoba has traditionally been known as a paramilitary stronghold. Santa Fe de Ralito, a former home base for AUC leader Salvatore Mancuso and where the Colombian government brokered a deal for paramilitary demobilisation in 2003, was not too far away in the same department (Córdoba). There was also a very limited to no ELN presence in the vicinity where FARC fronts would have been previously operating. In contrast, 
parts of the Cauca department had been dominated by FARC, but various paramilitary groups and the ELN have also all recently held presence there. In addition to this, the camps varied in size. The Tierralta camp was a 'Punto Transitorio', or a small demobilisation camp, with only one encampment (one FARC front), with around 50 FARC fighters, whereas both San Jose and Buenos Aires were large Zona Veredales where multiple fronts had coalesced, with around 200-400 people.

I selected respondents in these camps based on a convenience sample with the permission of one or more of the FARC commanders. All respondents were FARC members undergoing disarmament with the collective 'reincorporation' process. I interviewed respondents from various positions, including commanders, sub-commanders, militias, negotiators (in Havana, Cuba) and rank-and-file 'soldiers'. Respondents were also from various age groups (between 30-75 years old). There were an equal number of female and male FARC respondents. All the interviewees signed anonymity agreements.

Most of the questions in the survey were scale gauges or multiple choice. However, some open-ended questions were included. The survey consisted of three sections. The first section contained demographic information, age, gender, the length of time as FARC member, official ranking or position, and where they were operational. The second section first asked respondents to rank from ' 0 ' to ' 100 ' the level of threat they perceived to their personal safety from each of the four potential rival group (BACRIM, paramilitaries, the Armed Forces/Government, and the ELN), '0' indicating 'no threat at all' and '100' indicating 'high threat'. Next, it contained a series of statements about perceptions of threat to personal safety, threats to the peace process, and to various collectives the participant may be a member of (i.e. the FARC, their local community, progressive social movements, political groups) posed by each potential rival actor (BACRIM, paramilitaries, the Armed Forces/Government, and the ELN). It asked the respondents to rank these statements from ' 1 ' to ' 5 ', ' 1 ' being 'totally disagree' to ' 5 ' being 'totally agree' as a gauge of the perceived level of threat. For example, respondents were asked to what extent they agreed with statements such as 'Paramilitaries represent a threat to the peace process'. It posed the exact same set of statements for each rival actor. It then presented various statements regarding the extent to which respondents trusted each actor and how they viewed their future interactions after disarmament and reintegration. I also simultaneously asked questions concerning the nature of the threat and the nature of the rivalry they experienced with each set of rival actor. Given that commitment problems may only exist between the government and the FARC, the survey contained an extended set of 
questions pertaining to trust in the government in the short and long-term. In the final section of the survey I offered each an opportunity to speak more openly.

\section{FARC perceptions of threat in the context of multiple armed groups}

In the sections below, I highlight FARC interviewees' perceptions of threat or insecurity visà-vis various armed groups present in the Colombian conflict. First, I present FARC respondents' views and trust that the Colombian government (and its armed forces) are committed to peace and how the presence of other actors seems to have influenced this. Next I focus on how FARC respondents' perceived insecurity coming from pro-state paramilitary groups (and BACRIM), and finally the ELN. Each section examines FARC member immediate perceptions of threat to their safety (i.e. fear of being militarily targeted) as well as fear that they might be collectively targeted. It then gauges FARC member perceptions of trust in that group in the future (i.e. long-term).

\section{FARC and the government (and its armed forces)}

Interviewed FARC members in all three camps perceived very low to minimal threat to their personal and collective physical safety from the government and its armed forces during the disarmament process as well as looking into their future reintegration. In the surveys, very few respondents rated the government and its armed forces as a major threat to their personal safety. Only one respondent rated the government and its armed forces as more of a physical threat to their personal safety as the successor paramilitary forces (see below). Very few, but with a slightly higher average, saw the government and its armed forces as a physical threat towards members of their community, social movements and unions, or their political party representatives. Only 3 out of 16 respondents classified the government and its armed forces as an 'enemy'.

Interviewed FARC members also expressed that they trusted that the Colombian government and its armed forces would not violently target them during the FARC's transition

from conflict to peace. ${ }^{41}$ One respondent forcefully argued 'I highly doubt that we will see a repeat of what happened with the Union Patriótica. The state wants peace, as do we. ${ }^{42}$ Respondents detailed how trust between the FARC and the government had been built during the years of negotiations. One respondent who was present in Havana for the negotiations stated, 'the government has worked hard to earn our trust and to show us that they are dedicated to peace during the negotiations' ${ }^{43}$ Another FARC member that was present at 
negotiations in Havana argued that with the presence of the UN, the MMV, international nongovernment organisations (NGOs) and observers, as well as the international attention the peace process has garnered, particularly after Santos won the peace prize, it would be extremely unlikely that the government and its armed forces would openly revert to militarily targeting FARC members participating in the peace process. ${ }^{44}$ Other respondents emphasised that while the government and armed forces as a whole seemed committed to upholding the peace process, there were certain elements within the military that were still hostile to the peace process. In other words, many recognised that the government was not a unitary entity.

However, there were significant perceived security threats in one case. In April 2017, just before the disarmament process, FARC respondents in the camp in Córdoba ('Gallo') alleged the Army had staged set-ups ('montajes') to provoke the FARC, stating, referring to the Army outside the FARC camp, 'there are tensions with our former enemies. ${ }^{45}$ Respondents in this camp described how they distrusted both the police and military in the security perimeter set up surrounding the camp, and alleged that they were monitoring FARC activities. Many respondents outlined that these tensions were largely due to the government not providing promised materials for the camps. One respondent claimed that she did not trust the government to protect her during the disarmament process and whilst in the camps, connecting this mistrust to the lack of provisions from the government. She said, 'I feel unprotected. Now that the government is not fully complying with its end of the deal [with respect to provisions and materials in the camps], I am losing trust that the government will provide for my security. ${ }^{46}$

Conditions in this camp improved in my second visit in July. Respondents this time around outlined continued dialogue with the government and enhanced material provisions as reasons for their optimism during disarmament. Commanders and sub-commanders from other camps answered these questions form a more historical and political perspective. One subcommander stated 'it is difficult to trust the government. In the past, the government have broken their promises after many negotiations and deals and targeted us. ${ }^{47}$ In summary, despite the general consensus in trusting that the government and its armed forces would not military target demobilizing individuals, this perspective was nuanced.

While it appeared most of the interviewed FARC members were not afraid that the government would militarily target them, there was less trust that the government would adequately provide for their security against other armed groups once the FARC lay down arms. For example, when asked to gauge the extent to which they agreed with the statement 'I can trust that the government (and police, etc.) will protect me from threats to my personal 
security', over half responded negatively. The paramilitaries were viewed as the main threat (see below), but the government, in FARC respondents' eyes, was not doing enough to protect them, and were seen to have abandoned the security stipulations in the peace agreement. One respondent claimed that 'The disarmament process has not ended yet. The security situation is very serious, and the state has not taken action against paramilitaries. We are disarming despite the threat from other groups only to demonstrate our commitment to the promise of peace. ${ }^{48}$ Many high-ranking respondents alleged that the military turned a blind eye to paramilitary operations in the region. ${ }^{49}$ Moreover, many respondents viewed that the government was perpetuating the conditions that allowed paramilitaries to function. Around two-thirds of respondents thought that the government still had significant clandestine links with paramilitary groups and linked threats to their personal safety to the government's unwillingness to tackle paramilitaries. Another interviewee was clear that 'in order to dismantle the paramilitaries, the government needs to terminate the politics and structures that support them. ${ }^{50}$ FARC members that were in Havana stated that during the negotiations the government agreements in addressing continued paramilitary activity as well as providing adequate security for demobilizing FARC members were major sticking points, but that the state had stopped short of fully dismantling paramilitary groups. ${ }^{51}$

In addition to this, there were relatively low levels of trust that the government would fulfil its end of the bargain in the long-term. For example, when asked about the future, most respondents did not trust that the government would implement the agreed terms of the peace deal or that the government had the capacity to do so. There was significantly less trust that the Colombian government would allow real political change in the long-term. Even fewer thought that the government had the best interests of demobilizing FARC members in mind during this peace process. One respondent argued 'the state doesn't really care about us or what happens with us. They are just happy if we disarm and disappear. ${ }^{, 52}$ Despite this, many respondents had an optimistic outlook for the future and the FARC's collective role in politics in its transition to a political party as well as a personally positive outlook in their reintegration. One stated, 'With the government we hope that the signed agreements are honoured and implemented. But this isn't just about giving up weapons. We also hope for development in the country-side and opportunities for the community to reach its political and economic potential. ${ }^{, 53}$ 
In my interviews and surveys I had initially prepared the same questions relating to BACRIM and paramilitaries as separate actors, but all interviewed FARC members rejected this distinction. All interviewed FARC members in this study not only viewed BACRIM and paramilitaries as one and the same, but also understood the contemporary paramilitaries as a continuation from the AUC era. They also related that not much had changed since the paramilitary demobilisation in terms of their relationships to paramilitary actors. One was clear that 'for us the so-called BACRIM and paramilitaries are the same because they have the same politics. ${ }^{54}$ Another said, 'BACRIM is the name given to the various actors that continued the work of the paramilitaries, displacing, chasing out, and killing the local populations. In our communications BACRIM and paramilitaries are treated as the same. ${ }^{55}$ All interviewees rejected the notion that BACRIM represented a separate category of armed groups that was apolitical and only interested in drug trafficking, as the government of Colombia often claimed. Some respondents acknowledged differences between groups, however. One respondent outlined how some paramilitary groups operated as military units, such as the AGC, whereas others were described as 'ghost assassins', such as the Águilas Negras, not really holding much of a physical presence and domination of territory but appearing where necessary to use violence to further their right-wing political agenda. ${ }^{56}$

Respondents all said they experienced significant threat to their personal safety from paramilitary forces. In the surveys, on a scale of 0-100 with 0 being 'no threat' at all and 100 'high threat', all except for one rated the personal level of threat from paramilitaries above 50, with the most common answer '100' (six out of 16 respondents). Respondents described security tensions with paramilitary groups whilst in the camps as well as in their forecasts for the future. Two FARC commanders in one camp described potential military confrontations between the two groups including how paramilitary members had approached the perimeter of their camp at night. ${ }^{57}$ One respondent claimed 'we are surrounded by paramilitaries', pointing to the mountains nearby, and most agreed that the paramilitaries considered FARC members a military target. ${ }^{58}$ In July 2017, after disarmament, one FARC member stated that 'the paramilitaries have always been our enemy and we are worried about our insecurity being without arms. ${ }^{59}$ Another described how he felt safer in the camps than outside of them and was worried that the state could not or would not do anything to protect him after he leaves the camp. ${ }^{60}$ Generally speaking, amongst respondents there was not much optimism that they would be safe from paramilitary violence after disarmament and after leaving the camps. One interviewee related that paramilitary violence against him and his family was one of the main 
reasons why he joined the FARC in the first place and he did not expect that to he would be treated differently in the future. ${ }^{61}$ Another stated, 'if the government fulfils its terms of the agreement and takes steps to implement the peace process, the paramilitaries will not leave us alone. ${ }^{62}$

In addition to a threat to their personal safety, all FARC respondents agreed that paramilitaries were a threat to the peace process, to their communities, to social movements, and their political party representatives. All except for two respondents classified paramilitaries as 'enemies' to some degree (the two others did not agree or disagree). Many were worried that paramilitary forces would obstruct FARC participation in politics by assassinating or 'violently opposing' the politicians that represent their interests, including when the FARC becomes a political group. Others were afraid that a paramilitary massacre of FARC political representatives, similar to that of the UP in the 1980s, could provide the basis for future conflict. $^{63}$

Respondents described the sense of threat emanating from paramilitary groups as affecting their decision to disarm or their perspective on the disarmament process. When asked why FARC members disarmed despite potential dangers, a common narrative was that they were taking a risk for peace. For example, one stated 'We experience fear of the state and the paramilitaries. We experience insecurity. I could only lay down arms due to my confidence in the peace process and with our conviction that the best way to end this armed conflict is by joining the political process. ${ }^{64} \mathrm{He}$ described the disarmament process and his involvement in the peace process more generally as a 'necessary risk' for a more peaceful Colombia. One FARC militia member said that 'The rivalry we have with the paramilitaries is over the control of territory, over power, and the political direction of the country. The FARC have always pursued a change in society to get rid of inequalities, but the paramilitaries have always looked to gain access to resources for themselves and their superiors, killing campesinos in order to do so.' He continued, 'For the moment our rivalries with the paramilitaries have not affected my disarmament or demobilisation because what we agreed to with the government is clear. The problem is that if the paramilitaries come to kill us, now that we have disarmed we have nothing to defend ourselves with. But we are committed to peace. It is a risk we have to take. ${ }^{65}$ Another said, 'Our word and promises to the Colombian people are important despite the risks, we also have the will power to see this through and to show the world who we are. ${ }^{66}$ 


\section{FARC and the ELN}

There was a stark contrast between different locations in how FARC members perceived a threat from the ELN. In camps in Córdoba and Guaviare, areas where there was little to no ELN presence, respondents rated their perception of threat to their personal safety from ELN as '0'. ${ }^{67}$ Correspondingly, all respondents in these two areas 'completely disagreed' that the ELN posed a threat to the Government-FARC peace process, to FARC communities, social movements, and to their political party representatives. None considered the ELN as an 'enemy'. Moreover, far from considering the ELN as potential rivals or spoilers to peace, many respondents referred to the ELN as 'friends' or 'brothers and sisters in arms' with the FARC in that they had similar revolutionary objectives. ${ }^{68}$ FARC members with more experience, respondents over the age of 50, in both camps stated that because the ELN were not present in their areas, there was no FARC-ELN rivalry or competition, but that they were not sure about other areas. ${ }^{69}$

In contrast, in Cauca, where the ELN had a relatively strong presence, respondents perceived the ELN as a strong threat to their personal safety. The higher the rank, the higher the respondent tended to rate the threat to their personal safety as well as the perceived threats to the peace process, communities, social movements, and FARC political party representatives. Respondents rated the ELN, on average, as much less of a threat than paramilitaries, but perceived the ELN in these areas as more of a threat, on average, than the government and its armed forces. In interviews one FARC commander in Cauca detailed that the ELN were a threat to his personal safety and the FARC collectively in three main ways. First, he said that a few years prior the FARC and ELN commands in his region held a series of meetings in which the ELN accused the FARC of being 'traitors' to the revolutionary cause by entering into the peace agreement with the government. 'There is a chance', he said, 'but a very unlikely one, that ELN could militarily target FARC members.' He stated 'as long as there is no peace deal between the ELN and the government, the ELN represent a threat to the FARC reincorporation and peace in the country.' Secondly, as ELN expand their control over communities previously held by FARC, the ELN tax local communities and could possibly punish some members of those communities for cooperation with the FARC. He said the FARC felt a 'responsibility to protect those communities from reprisals'. Finally, and similarly, he said the process of ELN establishing control of territory previously held by the FARC could lead to violence against FARC members and communities. ${ }^{70}$ 


\section{Conclusions}

This article offers a glimpse into how demobilizing FARC members perceived insecurities associated with the credible commitment problem in the context of multiple warring groups. It highlights how FARC members' trust in the government's commitment to implementing the peace agreement was influenced by excluded armed groups. It also sheds some light on demobilizing members' perception of threat vis-à-vis other armed groups that have continued activities despite the government-FARC peace agreement.

Interviewed demobilizing FARC members, for the most part, trusted that the government and its armed forces would not violently target them during their disarmament or reintegration in the future. However, they expressed doubt in the government's commitment to the implementation of the peace agreement, especially regarding the government's commitment to their physical security vis-à-vis armed groups excluded from the governmentFARC agreement. In addition, FARC members expressed that these excluded armed groups posed a significant threat to their personal safety during their disarmament and in their future reintegration due to continued rivalries, personal retaliation, or from forced recruitment. Many were also concerned about paramilitary actors targeting FARC ex-combatants, political party members, and social and community leaders and activists, threatening FARC inclusion into the political process. A few were afraid of ELN reprisals for being 'traitors' to the armed revolutionary cause.

This article offers a snapshot of FARC members' perceptions during disarmament in April and July 2017. Since then, conservative President Iván Duque’s administration, elected in 2018 on an anti-peace-process platform, has stalled on the implementation of some of the terms of the agreement. ${ }^{71}$ Previous research has indicated how breaking promises like this can erode armed groups' trust in the government's commitment to peace. ${ }^{72}$ While the majority of FARC fighters have continued 'reincorporation' ${ }^{, 73}$, some top- and middle- rank commanders, including alias 'Santrich', have returned to arms, lamenting the Duque administration's failure to implement the terms of the government-FARC agreement. ${ }^{74}$ Similarly, other 'dissident' FARC members have also returned to war citing threats from other armed groups, such as paramilitary forces. ${ }^{75}$ Indeed, the United Nations counted 173 ex-FARC members and estimated 324 (confirmed 303) social leaders have been assassinated from the signing of the peace agreement in 2016 through to December 2019, with many more killed since the beginning of $2020 .^{76}$ 
This article makes two related contributions to the literature on credible commitment problems during attempts to end civil conflict. First, this article suggests that the presence of extra-dyadic armed groups excluded from peace processes can affect credible commitment problems between a government and an insurgent group, at least on one side. ${ }^{77}$ The presence of external armed actors can impact insurgent member's perceptions of the government's commitment to the implementation of the terms of an agreement, especially where insurgents perceive that the government can influence excluded armed group activity.

Secondly, this article also suggests that continued activities of armed groups outside of government-insurgent peace processes can constitute the primary security dilemma impeding insurgent DDR. This corroborates existing research into the effects of continued competition with excluded armed groups on insurgent group DDR, and ultimately on conflict duration and conflict reoccurrence. ${ }^{78}$ It is also consistent with the literature on spoilers ${ }^{79}$ and on progovernment militias effects on the prospects for peace. ${ }^{80}$

Further research is required to make generalizable observations beyond the Colombian case, but anecdotal evidence points to similar dynamics elsewhere. For example, in Mindanao, Philippines, armed groups such as Christian militias and hard-line Islamist separatists that were excluded from the Comprehensive Agreement on the Bangsamoro (CAB) between the Philippine government Moro Islamic Liberation Front (MILF) (2014), have diminished MILF trust in the government's commitment to the agreement and created security dilemmas for MILF vis-à-vis other groups. ${ }^{81}$ In Sudan, the implementation of DDR programmes after the government in Khartoum and the Sudanese People's Liberation Army (SPLA) signed Sudan's Comprehensive Peace Agreement (2005) was significantly complicated by the presence of multiple excluded armed groups. ${ }^{82}$

These observations have policy implications for mitigating credible commitment problems and associated security dilemmas after negotiated settlements between governments and insurgent groups in the context of multiple warring parties. This research highlights how there is a small window of opportunity for warring parties to signal their commitment to the terms of a negotiated settlement, including by, but by no means limited to, addressing excluded armed groups. ${ }^{83}$ It also underscores the importance of security provisions for insurgent members undergoing DDR, including, potentially, institutional and third-party guarantees. ${ }^{84}$ In the case of Colombia, many have argued already that security for demobilizing FARC members must be a vital part of the implementation of any peace agreement between the government and the FARC. ${ }^{85}$ Further acknowledging insurgent perceptions of insecurity vis-à-vis excluded 
armed groups could be a useful departure for policymakers in designing transitions from conflict. 


\section{References}

Al Jazeera, 'UN: Colombia FARC Rebels Complete Disarmament'. Al Jazeera. 27 June 2017. https://www.aljazeera.com/news/2017/06/colombia-farc-rebels-completedisarmament-170626232629067.html

Aliyev, Huseyn, 2020. 'Pro-Regime Militias and Civil War Duration'. Terrorism and Political Violence 32(3), 630-650.

Aliyev, Huseyn, 2019. ' No Peace, No War' Proponents? How Pro-Regime Militias Affect Civil War Termination and Outcomes'. Cooperation and Conflict 54(1), 64-82.

Alto Comisionado Para La Paz, 2016a. 'Acuerdo Final Para la Terminación del Conflicto y la Construcción de una Paz Estable y Duradera'. Bogota: Colombia, November 24. http://www.altocomisionadoparalapaz.gov.co/procesos-yconversaciones/Documentos\%20compartidos/24-11-2016NuevoAcuerdoFinal.pdf

Alto Comisionado Para La Paz, 2016b. 'Zonas Veredales para la Dejación de Armas de las FARC'. Report of the Oficina del Alto Comisionado Para La Paz http://www.altocomisionadoparalapaz.gov.co/herramientas/Documents/Zonas-deubicacion.pdf

Annan, Jeannie, Moriah Brier, and Filder Aryemo, 2009. 'From 'Rebel' to 'Returnee': Daily Life and Reintegration for Young Soldiers in Northern Uganda'. Journal of Adolescent Research, 24(6) October, 639-667.

Arnold, Matthew, 2007. 'The South Sudan Defence Force: Patriots, Collaborators or Spoilers?'. Journal of Modern African Studies 45(4) December, 489-516.

Arnold, Matthew and Chris Alden, 2007. 'This gun is our food': Disarming the White Army militias of South Sudan: Analysis'. Conflict, Security \& Development 7(3), 361-385.

Ávila, Ariel, 2017. 'Bacrim, Neoparamilitares, y Grupos Post-Desmovilización Paramilitar'. Semana, March 30 2016. https://www.semana.com/opinion/articulo/ariel-avilabacrim-neoparamilitares-y-grupos-post-desmovilizacion-paramilitar/467330

Barltrop, Richard, 2008. 'The Negotiation of Security Issues in Sudan's Comprehensive Peace Agreement'. Country Study: Negotiating Disarmament. Centre for Humanitarian Dialogue. Number 2, March.

Berdal, Mats R. 1996. Disarmament and Demobilisation After Civil Wars: Arms, Soldiers and the Termination of Armed Conflicts. Oxford: Oxford University Press for the International Institute for Strategic Studies.

Bøås, Morten and Anne Hatløy, 2008. 'Getting In, Getting Out': Militia Membership and Prospects for Re-Integration in Post-War Liberia'. The Journal of Modern African Studies 46(1), 33-55.

Bouvier, Virginia Marie, 2009. Colombia: Building Peace in a Time of War. Washington D.C.: United States Institute of Peace Press.

Brodzinsky, Sibylla, 'Colombia's Road to Peace: New Militia Threatens Stability with Bloodshed'. The Guardian, 7 April 2016. https://www.theguardian.com/world/2016/apr/07/colombia-peace-talks-farc-elnguerrilas-usuga-clan

Brown, Derek, 'Arms Decommissioning in Northern Ireland' The Guardian, 2 July 2001. https://www.theguardian.com/world/2001/jul/02/qanda.northernireland 
Burgess, Stephen, 2008. 'Fashioning Integrated Security Forces After Conflict'. African Security 1(2), 69-91.

Casey, Nicholas and Federico Rios Escobar, 'Colombia Struck a Peace Deal with Guerrillas, But Many Return to Arms'. The New York Times, 18 September 2018.

Cunningham, David, 2011. Barriers to Peace in Civil War. Cambridge: CUP.

Cusack, Jim, 'Official IRA 'Doomsday' Bunkers May Still Contain Thousands of Weapons'. Belfast Telegraph, 31 May 2015. https://www.belfasttelegraph.co.uk/news/northernireland/official-ira-doomsday-bunkers-may-still-contain-thousands-of-weapons$\underline{31267631 . h t m l}$

Colombian National Reincorporation Agency 2020, 'ARN en Cifras' Report by the Colombian National Reincorporation 31 January 2020, Available online at http://www.reincorporacion.gov.co/es/reincorporacion/La\%20Reincorporacion\%20en $\% 20$ cifras/Reincorporaci\%C3\%B3n\%20en\%20cifras\%20$\% 20$ corte\%2031012020.pdf.

Daniels, Joe, 'Former Farc Commanders Say They are Returning to War Despite 2016 Peace Deal' The Guardian, 29 August 2019.

Derouen, Karl, Jenna Lea and Peter Wallensteen, 2009. 'The Duration of Civil War Peace Agreements', Conflict Management and Peace Science 26(4), 367-387.

Driscoll, Jesse, Wendy Pearlman and Kathleen G. Cunningham, 2012. 'Commitment Problems or Bidding Wars? Rebel Fragmentation as Peace Building'. Journal of Conflict Resolution 56(1), 118-149.

El Tiempo, 'El Paso a Paso para la Dejación de Armas de las Farc'. El Tiempo, 23 June 2016. https://www.eltiempo.com/archivo/documento/CMS-16628106

El Tiempo, 'Durante la Cuarentena, Cada Tres Días Asesinan a un Líder: MOE'. El Tiempo, 10 June, 2020. https://www.eltiempo.com/politica/proceso-de-paz/durante-lacuarentena-cada-tres-dias-asesinan-a-un-lider-moe-505330

Fearon, James, 2004. 'Why Do Some Civil Wars Last So Much Longer Than Others? Journal of Peace Research 41(3): 275-301.

Fearon, James, 1998. 'Commitment Problems and the Spread of Ethnic Conflict'. In The International Spread of Ethnic Conflict, edited by David Lake and Donald Rothchild. Princeton: Princeton University Press.

Filippidou, Anastasia and Thomas O'Brien, 2020. 'Trust and Distrust in the Resolution of Protracted Social Conflicts: The Case of Colombia'. Behavioral Sciences of Terrorism and Political Aggression Online first: 29 June.

Ghais, Suzanne, 2019. 'Consequences of Excluding Armed Groups from Peace Negotiations: Chad and the Philippines'. International Negotiation 24(1), pp.61-90.

Gill, Stephen, 'Colombia's Post-AUC Paramilitaries Left More than 320,000 Victims to Date'. Colombia Reports, 29 April 2016. https://colombiareports.com/colombias-neoparamilitaries-already-left-320000-victims/

Gonzalez Posso, Camilo and Carlos Eduardo Espitia, 2017. 'XIII Informe sobre presencia de grupos narcoparamilitares: primer semestre 2017'. Report by Indepaz, October. http://www.indepaz.org.co/wp-content/uploads/2017/10/Informe-2017-narcoparas.pdf

Gomez-Suarez, Andrei, 2010. 'US-Colombian Relations in the 1980s: Political Violence and 
the Onset of the UP Genocide,' in State Violence and Genocide in Latin America: The Cold War Years, 152-166. Edited by Esparza, M, Feierstein, D and Huttenbach, HR. Oxon, United Kingdom: Routledge.

Gomez-Suarez, Andrei, and Jonathan Newman. 2013. 'Safeguarding Political Guarantees in the Colombian Peace Process: Have Santos and FARC Learnt the Lessons from the Past?'. Third World Quarterly 34(5), 819-837.

Hartzell, Caroline, 1999. 'Explaining the Stability of Negotiated Settlements to Intrastate Wars', Journal of Conflict Resolution 43(1), 3-22.

Hartzell, Caroline, and Hoddie, M., 2003. 'Institutionalizing peace: power sharing and postcivil war conflict management'. American Journal of Political Science 47(2), 318-332.

Hartzell, Caroline, and Hoddie, M. 2007. Crafting peace: Power-sharing institutions and the negotiated settlement of civil wars. Penn State Press.

Hartzell, Caroline, Hoddie, M., and Rothchild, D., 2001. 'Stabilizing the Peace After Civil War: An Investigation of Some Key Variables’. International organization, 55(1), 183-208.

Hristov, Jasmin, 2009. Blood and Capital: The Paramilitarization of Colombia. Toronto: Between the Lines.

Holmes, Jennifer, Mendizabal, A. P., De La Fuente, D. S., Callenes, M., and Cárdenas, Á. 2019. 'Paramilitary Violence in Colombia: A Multilevel Negative Binomial Analysis'. Defence and Peace Economics, Online first: June 2019, 1-27.

Human Rights Watch. 2010. Paramilitaries' Heirs: The New Face of Violence in Colombia. New York: Human Rights Watch.

Humphreys, Macartan, and Jeremy Weinstein, 2007. 'Demobilization and Reintegration'. Journal of Conflict Resolution 51(4), 531-567.

Jennings, Kathleen, 2007. 'The Struggle to Satisfy: DDR Through the Eyes of Ex-Combatants in Liberia'. International Peacekeeping 14(2), 204-218.

Joshi, Madhav and Erik Melander, 2017. 'Explaining Demobilization in the Wake of Civil Conflict'. Peacebuilding 5(3), 270-288.

Kirschner, Shanna, 2010. 'Knowing Your Enemy: Information and Commitment Problems in Civil Wars'. Journal of Conflict Resolution 54(5), 745-770.

Kingma, Kees, 2002. 'Demobilization, Reintegration and Peacebuilding in Africa. International Peacekeeping 9(2), 181-201.

Kreutz, Joakim, and Enzo Nussio, 2019. 'Destroying Trust in Government: Effects of a Broken Pact among Colombian Ex-Combatants'. International Studies Quarterly 63(4), 11751188.

Longo, Matthew and Ellen Lust, 2009. 'The Case for Peace Before Disarmament'. Survival 51(4), 127-148.

Maher, David and Andrew Thomson, 2018. 'A Precarious Peace? The Threat of Paramilitary Violence to the Peace Process in Colombia'. Third World Quarterly, 39(11), 21422172 .

Muggah, Robert, Mats Berdal, Stina Torjesen, 2009. 'Conclusions: Enter an Evidence-Based Security Promotion Agenda'. In: Muggah, R (ed.) Security and Post-Conflict Reconstruction: Dealing with Fighters in the Aftermath of War. London and New York: Routledge, 268-284. 
Nasi, Carlo, 2006. 'Spoilers in Colombia: Actors and strategies.' In Challenges to Peacebuilding: Managing Spoilers During Conflict Resolution, edited by Edward Newman and Oliver Richmond, 219-242. Tokyo and New York: United Nations University Press.

Nilsson, Anders 2005. Reintegrating Ex-Combatants in Post-Conflict Societies. Swedish International Development Cooperation Agency.

Nilsson, Desiree, 2008. 'Partial Peace: Rebel Groups Inside and Outside of Civil War Settlements.' Journal of Peace Research 45(4), 479-495.

Nussio, Enzo, 2011. 'How Ex-Combatants Talk About Personal Security. Narratives of Former Paramilitaries in Colombia'. Conflict, Security \& Development 11(5), 579-606.

Nussio, Enzo, 2012. 'Emotional Legacies of War Among Former Colombian Paramilitaries'. Peace and Conflict: Journal of Peace Psychology 18(4), 369-383.

Nygård, Havard and Michael Weintraub, 2015. 'Bargaining Between Rebel Groups and the Outside Option of Violence. Terrorism and Political Violence 27(3), 557-580.

Mattes, Michaela and Burcu Savun, 2009. 'Fostering Peace After Civil War: Commitment Problems and Agreement Design'. International Studies Quarterly 53(3), 737-759.

O'Kane, Eamonn, 2007. 'Decommissioning and the Peace Process: Where Did it Come From and Why Did it Stay So Long?'. Irish Political Studies 22(1), 81-101.

Phayal, Anup, Prabin Khadka and Clayton Thyne, 2015. 'What Makes an Ex-Combatant Happy? A Micro-Analysis of Disarmament, Demobilization, and Reintegration in South Sudan'. International Studies Quarterly 59(4), 654-668.

Phillips, Brian, 2015. 'Enemies with Benefits? Violent Rivalry and Terrorist Group Longevity.' Journal of Peace Research 52(1): 62-75.

Presidencia de la República de Colombia, 2017. 'Dejación de Armas'. Website of Presidencia de la República de Colombia. Accessed 1 August 2019

http://especiales.presidencia.gov.co/Documents/20170620-dejacion-armas/dejacionde-armas.html

Pugel, James, 2007. 'What the Fighters Say: A Survey of Ex-Combatants in Liberia'. A report for United Nations Development Programme, Liberia, April 2007. http://www.operationspaix.net/DATA/DOCUMENT/904 v What_the_Fighters_Say _A_Survey_of_Ex-combatants_in_Liberia.pdf

Quinn, Jason, Madhav Joshi and Erik Melander, 2019. 'One Dyadic Peace Leads to Another? Conflict Systems, Terminations, and Net Reduction in Fighting Groups'. International Studies Quarterly 63(4) December, 863-875.

Reiter, Andrew, 2015. 'Does Spoiling Work? Assessing the Impact of Spoilers on Civil War Peace Agreements'. Civil Wars 17(1), 89-111.

Reiter, Andrew, 2016. Fighting Over Peace: Spoilers, Peace Agreements, and the Strategic Use of Violence. Springer.

Stedman, Stephen, 1997. 'Spoiler Problems in Peace Processes'. International Security 22(2), 5-53.

Spear, Joanna, 1999. 'The Disarmament and Demobilisation of Warring Factions in the Aftermath of Civil Wars: Key Implementation Issues'. Civil Wars 2(2), 1-22. 
Steinert, Cristoph, Janina Steinert and Sabine Carey, 2019. 'Spoilers of Peace: ProGovernment Militias as Risk Factors for Conflict Recurrence'. Journal of Peace Research 56(2), 249-263.

United Nations Human Rights Council, 2019. 'Visit to Colombia: Report of the Special Rapporteur on the situation of human rights defenders, Forty-third session 24 February20 March 2020'. Report for United Nations Human Rights Council, 26 December 2019. https://reliefweb.int/sites/reliefweb.int/files/resources/A_HRC_43_51_Add.1_E.pdf

United Nations Security Council, 2019. 'United Nations Verification Mission in Colombia: Report of the Secretary-General'. Report for United Nations Security Council, 26 December 20019. https://ugn9i3f3byc1y2ro6r6pfu7e-wpengine.netdnassl.com/files/191226_un_colombia.pdf

United States Congress, Committee on Foreign Affairs. Subcommittee on the Western Hemisphere, 2007. U.S.-Colombia Relations: Hearing Before the Subcommittee on the Western Hemisphere of the Committee on Foreign Affairs, House of Representatives, One Hundred Tenth Congress, First Session, Volume 4, April 24, 2007.

Velázquez Rivera, Edgar de Jesús. 2007. 'Historia del Paramilitarismo en Colombia' Historia, Sao Paolo 26(1), 134-153. http://www.scielo.br/pdf/his/v26n1/a11v26n1.pdf

Walter, Barbara, 2002. Committing to Peace: The Successful Settlement of Civil Wars. Princeton University Press.

Walter, Barbara, 1999. 'Designing Transitions from Civil War: Demobilization, Democratization, and Commitments to Peace.' International Security 24(1), 127-155.

\section{End Notes}

${ }^{1}$ Walter, 'Designing Transitions from Civil War'; Walter, Committing to Peace; Fearon,

'Why do Some Civil Wars'

${ }^{2}$ Kirschner, 'Knowing Your Enemy'

${ }^{3}$ Stedman, 'Spoiler Problems'; Reiter, 'Does Spoiling Work?'; Reiter, Fighting Over Peace.

${ }^{4}$ Walter, 'Designing Transitions from Civil War'; Walter, Committing to Peace;

${ }^{5}$ Nilsson, 'Partial Peace'; Quinn, et al, 'One Dyadic Peace'; Cunningham, Barriers to Peace; Ghais, 'Consequences of Excluding Armed Groups'.

${ }^{6}$ Nussio, 'How Ex-combatants Talk About Personal Security'; Nussio, 'Emotional Legacies'; Jennings, 'The Struggle to Satisfy'; Annan et al., 'From 'Rebel' to 'Returnee'.

${ }^{7}$ Walter, 'Designing transitions from civil war'; Walter, Committing to Peace.; Fearon, 'Why do Some Civil Wars'

${ }^{8}$ Walter, 'Designing Transitions from Civil War', 134.

${ }^{9}$ Berdal, Disarmament and Demobilization; Bøås and Hatløy, 'Getting In, Getting Out' .

${ }^{10}$ O'Kane, 'Decommissioning and the Peace Process; Brown, 'Arms Decommissioning in

Northern Ireland'

${ }^{11}$ Cusack, 'Official IRA 'Doomsday' Bunkers'

${ }^{12}$ Walter, 'Designing Transitions from Civil War'; Walter, Committing to Peace.; Mattes and Savun, 'Fostering Peace After Civil War'; Hartzell and Hoddie, 'Institutionalizing Peace'; Hartzell and Hoddie, 'Crafting Peace'; Hartzell et al., 'Stabilizing the Peace After Civil War'; Burgess, 'Fashioning Integrated Security Forces'; Fearon, 'Commitment Problems' ${ }^{13}$ Ghais, 'Consequences of Excluding Armed Groups'.

${ }^{14}$ Kirschner, 'Knowing Your Enemy'. 
${ }^{15}$ Quinn et al., 'One Dyadic Peace Leads to Another'; Kreutz and Nussio, 'Destroying Trust in Government'; Nilsson, 'Partial Peace'.

${ }^{16}$ Driscoll, 'Commitment Problems or Bidding Wars?'; Nygård and Weintraub, 'Bargaining Between Rebel Groups'; Steinert, et al., 'Spoilers of Peace: Pro-Government Militias'.

${ }^{17}$ Nilsson, 'Partial Peace'.

${ }^{18}$ Reiter, Does Spoiling Work?'; Reiter, Fighting Over Peace

${ }^{19}$ Steinert et al., 'Spoilers of Peace: Pro-Government Militias'; Aliyev, 'Pro-Regime Militias and Civil War Duration'; Aliyev, 'No Peace, No War'.

${ }^{20}$ Phillips, 'Enemies with Benefits?'.

${ }^{21}$ Berdal, Disarmament and Demobilization; Kingma, 'Demobilization, Reintegration and Peacebuilding'; Nussio, 'How Ex-Combatants Talk About Personal Security'.

${ }^{22}$ Humphreys and Weinstein, 'Demobilization and Reintegration'; Reiter, Fighting over

Peace; Bøås and Hatløy, 'Getting In, Getting Out'; Kingma, 'Demobilization, Reintegration and Peacebuilding'.

${ }^{23}$ Nussio, 'How Ex-Combatants Talk About Personal Security'.

${ }^{24}$ Jennings, 'The Struggle to Satisfy'; Phayal et al., 'What Makes an Ex-Combatant Happy?'; Pugel, 'What the Fighters Say'.

${ }^{25}$ Phillips, 'Enemies with Benefits?'; Velázquez, 'Historia del Paramilitarismo en Colombia'; Hristov, Blood and Capital;

${ }^{26}$ Maher and Thomson, 'A Precarious Peace?'.

${ }^{27}$ Gomez-Suarez, 'US-Colombian Relations in the 1980s'; Nasi, 'Spoilers in Colombia'.

${ }^{28}$ Nasi, 'Spoilers in Colombia', 225-227.

${ }^{29}$ Bouvier, Colombia: Building Peace in a Time of War.

${ }^{30}$ Nasi, 'Spoilers in Colombia', 234.

31 United States Congress, U.S. Colombia Relations.

${ }^{32}$ Gonzalez and Espitia, XIII Informe Sobre Presencia de Grupos Narcoparamilitares; Gill, 'Colombia's Post-AUC Paramilitaries'; Ávila, 'Bacrim, Neoparamilitares'.; Human Rights Watch, Paramilitaries' Heirs.

${ }^{33}$ Alto Comisionado Para La Paz, 'Zonas Veredales Para la Dejación de Armas'.

${ }^{34}$ Presidencia de la República de Colombia, 'Dejación de Armas'; El Tiempo, 'El Paso a Paso'.

${ }^{35}$ Presidencia de la República de Colombia, 'Dejación de Armas'; Al Jazeera, 'UN:

Colombia FARC Rebels Complete Disarmament'.

${ }^{36}$ Alto Comisionado Para La Paz, Acuerdo Final.

${ }^{37}$ Such as the Pacto Politico Nacional; la Comisión Nacional de Garantías de Seguridad; la Unidad Especial de Investigación; el Cuerpo Élite en la Policía Nacional; el Sistema Integral de Seguridad para el Ejercicio de la Política; el Programa Integral de Seguridad y

Protección para las Comunidades y Organizaciones en los Territorios

${ }^{38}$ Policía Nacional de Colombia, 'Agamenón'; Brodzinsky, 'Colombia's Road to Peace'

${ }^{39}$ United Nations Human Rights Council, Visit to Colombia; United Nations Security Council, United Nations Verification Mission in Colombia.

${ }^{40}$ Maher and Thomson, 'A Precarious Peace?'; Holmes et al., 'Paramilitary Violence in Colombia'.

${ }^{41}$ Author interview with anonymous FARC respondents 13-16, ZVTN camp 'La Elvira' in Cauca, 24 July 2017; and Author interview with anonymous FARC respondent 17, ZVTN camp 'Gallo' in Córdoba, 23 April, 2017.

${ }^{42}$ Author interview with anonymous FARC respondent 13, ZVTN camp 'La Elvira' in Cauca, 24 July 2017.

${ }^{43}$ Author interview with anonymous FARC respondent 17, ZVTN camp 'Gallo' in Córdoba, 23 April 2017. 
${ }^{44}$ Author interview with anonymous FARC respondent 13, ZVTN camp 'La Elvira' in Cauca, 24 July 2017.

${ }^{45}$ Author interview with anonymous FARC respondent 17, ZVTN camp 'Gallo' in Córdoba, 23 April, 2017.

${ }^{46}$ Author interview with anonymous FARC respondent 3, ZVTN camp in San José del Guaviare, 7 July 2017.

${ }^{47}$ Author interview with anonymous FARC respondent 16, ZVTN camp 'La Elvira' in Cauca, 24 July 2017

${ }^{48}$ Author interview with anonymous FARC respondent 16, ZVTN camp 'La Elvira' in Cauca, 24 July 2017

${ }^{49}$ Author interview with anonymous FARC respondents 1 , ZVTN camp 'La Elvira' in Cauca, 18 April 2017; 12 and 16, ZVTN camp 'La Elvira' in Cauca, 24 July 2017; 17 and 18, ZVTN camp 'Gallo' in Córdoba, 23 April 2017.

${ }^{50}$ Author interview with anonymous FARC respondent 17, ZVTN camp 'Gallo' in Córdoba, 23 April 2017; Anonymous FARC respondent 18 had a very similar answer, ZVTN camp 'Gallo' in Córdoba, 23 April 2017.

${ }^{51}$ Author interview with anonymous FARC respondent 13, ZVTN camp 'La Elvira' in Cauca, 24 July 2017.

${ }^{52}$ Author interview with anonymous FARC respondent 4 and 5, ZVTN camp in San José del Guaviare, 7 July 2017

${ }^{53}$ Author interview with anonymous FARC respondent 1, ZVTN camp 'La Elvira' in Cauca, 18 April 2017.

${ }^{54}$ Author interview with anonymous FARC respondent 3, ZVTN camp in San José del Guaviare, 7 July 2017.

${ }^{55}$ Author interview with anonymous FARC respondent 1, ZVTN camp 'La Elvira' in Cauca, 18 April 2017.

${ }^{56}$ Author interview with anonymous FARC respondent 1, ZVTN camp 'La Elvira' in Cauca, 18 April 2017.

${ }^{57}$ Author interview with anonymous FARC respondents 17 and 18, ZVTN camp 'La Elvira' in Cauca, 24 July 2017.

${ }^{58}$ Author interview with anonymous FARC respondents $1,2,3,4,15,16,17$, ZVTN camps 'Gallo' in Córdoba, San José del Guaviare, 'La Elvira' in Cauca, 18 April, 7 July, and 24 July 2017.

${ }^{59}$ Author interview with anonymous FARC respondent 5, 6, ZVTN camp in San José del Guaviare, 7 July 2017, and anonymous FARC respondent 7, ZVTN camp 'Gallo' in Córdoba, 16 July 2017.

${ }^{60}$ Author interview with anonymous FARC respondent 21, ZVTN camp in San José del Guaviare, 7 July 2017, anonymous FARC respondent 22, ZVTN camp 'La Elvira' in Cauca, , 24 July, 2017.

${ }^{61}$ Author interview with anonymous FARC respondent 18, ZVTN camp 'Gallo' in Córdoba, 23 April, 2017.

${ }^{62}$ Author interview with anonymous FARC respondent 6, ZVTN camp in San José del Guaviare, 7 July 2017.

${ }^{63}$ Author interview with anonymous FARC respondent 2, 3, 4, 6, 7, 9, 10, 12, 14, 16, ZVTN camps 'Gallo' in Córdoba, San José del Guaviare, 'La Elvira' in Cauca, 18 April, 7 July, and 24 July 2017.

${ }^{64}$ Author interview with anonymous FARC respondent 15, ZVTN camp 'La Elvira' in Cauca, 24 July 2017.

${ }^{65}$ Author interview with anonymous FARC respondent 11, ZVTN camp 'Gallo' in Córdoba, 16 July 2017. 
${ }^{66}$ Author interview with anonymous FARC respondent 16, ZVTN camp 'La Elvira' in Cauca, 24 July 2017.

${ }^{67}$ One respondent from Chocó (where the ELN have a presence) but who was stationed in the camp in Córdoba rated the ELN as a '10' to his personal safety. He stated that the ELN might pose a threat should he return to the areas where he was operational as a FARC member in Chocó. Author interview with anonymous FARC respondent 7, ZVTN camp 'Gallo' in Córdoba, 16 July 2017.

${ }^{68}$ Author interview with anonymous FARC respondent 3, 4, 5, 7, 8 ,9, ZVTN camps San José del Guaviare and 'Gallo' in Córdoba, 7 July and 16 July 2017.

${ }^{69}$ Author interview with anonymous FARC respondent 5, 6, 9, ZVTN camps San José del Guaviare and 'Gallo' in Córdoba, 7 July and 16 July 2017.

${ }^{70}$ Author interview with anonymous FARC respondent 12, ZVTN camp 'La Elvira' in Cauca, 24 July 2017.

${ }^{71}$ Filippidou and O'Brien, 'Trust and Distrust'.

${ }^{72}$ Kreutz and Nussio, 'Destroying Trust in Government'

73 As of January 2020, the Colombian National Reincorporation Agency was unable to locate 821 ex-guerrillas out of 13,330 that had signed up to the agreement. This does not include numbers of FARC members that did not join the peace process from the beginning, which was an even smaller percentage of the total FARC members pre-2016 agreement. Colombian National Reincorporation Agency, 'ARN en Cifras'.

${ }^{74}$ Daniels, 'Former Farc Commanders Say They Are Returning to War'.

${ }^{75}$ Casey and Rios Escobar, 'Colombia Struck a Peace Deal With Guerrillas But Many Return to Arms'

${ }^{76}$ United Nations Human Rights Council, Visit to Colombia; United Nations Security Council, United Nations Verification Mission in Colombia; El Tiempo 'Durante la Cuarentena, Cada Tres Días Asesinan a un Líder: MOE'.

77 The literature explores credible commitment problems as dyadic, occurring between a government and an insurgent group. Walter, 'Designing Transitions from Civil War'; Walter, Committing to Peace; Fearon, 'Why do Some Civil Wars'; Longo and Lust, 'The Case for Peace Before Disarmament'; Spear, 'The Disarmament and Demobilisation of Warring Factions'.

${ }^{78}$ Phillips, 'Enemies with Benefits?'; Nilsson, 'Partial Peace'.

${ }^{79}$ Stedman, 'Spoiler Problems'; Reiter, 'Does Spoiling Work?'; Reiter, Fighting over peace.

${ }^{80}$ Steinert, et al., 'Spoilers of Peace: Pro-Government Militias'; Aliyev, 'Pro-Regime Militias and Civil War Duration'; Aliyev, 'No Peace, No War'.

${ }^{81}$ Ghais, 'Consequences of Excluding Armed Groups'.

${ }^{82}$ Barltrop, 'The Negotiation of Security Issues in Sudan's Comprehensive Peace Agreement'; Arnold, 'The South Sudan Defence Force'; Arnold and Alden, 'This Gun is Our Food'.

83 Joshi and Melander, 'Explaining Demobilization'; Derouen et al., 'The Duration of Civil War Peace Agreements'.

${ }^{84}$ Humphreys and Weinstein, 'Demobilization and Reintegration'; Walter, 'Designing Transitions from Civil War'; Hartzell, 'Explaining the Stability of Negotiated Settlements to Intrastate Wars'.

${ }^{85}$ Gomez-Suarez and Newman, 'Safeguarding Political Guarantees'. 